\title{
Koulutuksen ja työelämän yhteistyö pedagogisia näkökulmia ${ }^{1}$
}

\author{
Päivi Tynjälä ja Kaija Collin
}

\author{
Tiedon oppiminen ja tiedon käyttäminen eivät ole \\ erillisiä, vaan yhtä ja samaa prosessia. Oppiminen on \\ tilannesidonnaista ja sitä tapahtuu työssä ja työn kautta \\ osallistumalla aitoihin toimintakäytäntöihin. Nykyisin \\ suositellaankin sellaisia pedagogisia järjestelyjä, joissa \\ opiskelijat kohtaavat todellisen elämän ongelmat jo \\ opiskelun alkuvaiheissa ja opiskelevat teoriaa kytkettynä \\ näihin aitoihin arkielämän tilanteisiin.
}

Tarkastelemme tässä artikkelissa koulutuksen ja työelämän välistä yhteistyötä ja työssä oppimista pedagogisena ja tutkimuksellisena kysymyksenä. Koulutuksen ja työelämän yhteistyöllä on monia eri muotoja, kuten yliopistojen ja ammattikorkeakoulujen rekrytointipalvelut, tutkimuspalvelut ja kehittämisprojektit, työelämään liittyvät opinnäytetyöt ja harjoittelut sekä ammatillisten oppilaitosten opiskelijoiden työssäoppimisjaksot. Näistä käsittelemme etenkin opiskelijoiden työssä oppimiseen liittyviä kysymyksiä. Emme kuitenkaan rajaudu ainoastaan koulutukseen liittyvään työssä oppimiseen, vaan tarkastelemme aluksi työssä oppimisen yleisiä piirteitä työelämässä jo vakinaisesti olevien osalta. Englanninkielisessä kirjallisuudessa käytetään termiä workbased learning, jolla voidaan tarkoittaa sekä työntekijöiden oppimista työpaikoillaan että opiskelijoiden koulutukseen kuuluvaa työssä oppimista, joka voi muodoltaan vaihdella lyhyistä työpaikkaekskursioista pitkiin työssäolojaksoihin tai opinnäytetyön tekemisestä työelämäprojekteihin.
Koulutuksen ja työelämän välisen vuorovaikutuksen merkitystä ja opiskelijoiden työssä oppimista on perusteltu monista erilaisista teoreettisista lähtökohdista käsin. Esimerkiksi sosiokulttuurinen oppimisnäkemys ja oppimisen situaatioteoriat korostavat, että oppiminen tapahtuu vuorovaikutuksellisissa prosesseissa osallistumalla autenttisiin toimintakäytäntöihin (Brown ym. 1989; Darrah 1995; Rogoff 1991; Lave \& Wenger 1991). Samoin toiminnan teoria ja kehittävä työntutkimus integroivat työn ja oppimisen (Engeström 1995). Deweyn klassinen learningby-doing -idea korostaa konkreettisten kokemusten reflektoinnin merkitystä, samoin kuin kokemuksellisen oppimisen teoriat (Kolb 1984; Schön 1987). Viime vuosikymmenellä alettiin kiinnittää huomiota myös informaaliin ja satunnaisoppimiseen, mikä on tyypillistä nimenomaan työpaikalla tapahtuvalle oppimiselle (Marsick \& Watkins 1990). Myös konstruktivistisen oppimiskäsityksen ja kognitiivisen asiantuntijuustutkimuksen voidaan katsoa tukevan työssä oppimisen ideaa, sillä ne korostavat oppijan aktiivi- 


\section{A R T I K K E L I T}

suuden sekä teorian ja käytännön vuorovaikutuksen merkitystä oppimisessa ja asiantuntijuuden kehittymisessä (Bereiter \& Scardamalia 1993; Bromme \& Tillema 1995; Eteläpelto \& Light 1999; Leinhardt ym. 1995; Mäkinen ym. 1999; Tynjälä 1999; Tynjälä ym. 1997.) Omassa tarkastelussamme emme näe näitä erilaisia teoreettisia viitekehyksiä välttämättä toisiaan poissulkevina ja ristiriitaisina, vaan toisiaan täydentävinä erilaisina näkökulmina oppimiseen.

$\mathrm{J}_{\mathrm{p}}^{\mathrm{o}}$ otta voisimme ymmärtää työhön liittyviä oppimisprosesseja ja kehittää koulutuksen ja työn integraatiota, tarvitsemme tietoa siitä, miten ja mitä työssä ylipäätään voidaan oppia ja mitä erityispiirteitä työssä oppimiseen liittyy verrattuna kouluoppimiseen.

Lähdemme tarkastelussamme liikkeelle työssä jo olevien - ei siis opiskelijoiden - oppimisesta työn yhteydessä ja työpaikalla. Näemme työssä oppimisen keskeisenä tavoitteena asiantuntijuuden kehittymisen, ja tarkastelemme asiantuntijuuden luonnetta ja sen kehittämiseen liittyviä kysymyksiä. Esitämme keskeisiä oppimisen ja asiantuntijuuden tutkimuksesta nousevia näkökohtia työssä oppimiseen ja painotamme erityisesti teorian, käytännön ja itsesäätelytaitojen integroimisen tärkeyttä. Tämän jälkeen tarkastelemme työssä oppimisen ja koulutuksessa oppimisen eroja ja mahdollisia ongelmia, joita koulutuksen ja työn kytkeminen sisältää. Johtopäätöksemme on, että toisaalta tietoyhteiskuntakehityksen mukanaan tuomien tietointensiivisten tehtävien lisääntyminen ja toisaalta vuorovaikutuksellisuutta ja autenttisuutta korostavat uudet pedagogiset mallit ovat kaventamassa eroa työssä oppimisen ja kouluoppimisen välillä. Lopuksi esitämme haasteita työssä oppimisen sekä koulutuksen ja työelämän välisen yhteistyön tutkimukselle.

\section{TYÖSSÄ OPPIMISEN}

\section{LUONTEESTA: työntekijöiden työssä oppiminen}

$\mathrm{T}$ yössä oppiminen on tutkimusalueena varsin nuori. Siihen liittyviä kysymyksiä on tarkasteltu mm. organisaatiokulttuurien ja organisaa- tioissa tapahtuvan oppimisen tutkimuksen piirissä (esim. Argyris \& Schön 1996; Brown \& Duguid 1991), kehittävän työntutkimuksen alueella (Engeström 1995), reflektiiviseen ammattikäytäntöön liittyen (Marsick 1996), kontekstuaalisen oppimisen viitekehyksessä (Poikela 1999); sekä oppimista käytännön yhteisöihin osallistumisena tarkastelevassa kirjallisuudessa (Lave \& Wenger 1991; Wenger 1998).

$\mathrm{E}$ rilaisista teoreettisista lähtökohdista nouseva utkimus on nostanut esiin erilaisia työssä oppimiseen liittyviä käsitteitä ja prosesseja, mutta kirjavasta kentästä voidaan kuitenkin hahmottaa joitakin keskeisiä työssä oppimisen piirteitä, jotka näyttävät nousevan esiin tutkimussuuntauksesta riippumatta, toisissa eksplisiittisesti, toisissa implisiittisemmin. Eräs tällainen työssä oppimisen yleinen luonnehdinta on informaalisuus ja satunnaisuus; työssä opitaan usein tahattomasti, ilman formaalia opetusta ja koulutusta kytkeytyneenä jokapäiväiseen ongelmanratkaisuun (Argyris \& Schön 1996; Marsick \& Watkins 1991). Viime vuosina on alettu kiinnittää huomiota työssä oppimisen tekemiseen näkyväksi ja sen tukemiseen ja tätä varten on kehitetty erilaisia malleja (ks. Järvinen ym. 2000). Näissä malleissa 
noustaan informaalin ja satunnaisen työssä oppimisen tasolta kohti ohjatumpaa ja tavoitteellisempaa oppimista. Työssä oppiminen on myös kokemuksellista. Työssä oppimisen kokemuksellisuus tulee esille työntekijöiden tuntemuksena siitä, että työtä ja työssä oppimista on vaikea erottaa toisistaan. Työ itsessään sisältāä oppimista silloin, kun ratkotaan jokapäiväisiä ongelmatilanteita, kerrytetään kokemusvarastoa, opitaan virheistä ja pohditaan yhdessä kollegojen kanssa työn ongelmallisia kohtia.

Lisäksi työssä oppimiselle on tyypillistä yhteisöllisyys, mikä ilmenee osallistumisena tietyn käytännön yhteisön (community of practice) toimintaan. Oppiminen voidaankin nähdä osana arjen toimintakäytäntöjä, jotka ovat ajan myötä tapahtuneen sosiaalisen muovautumisen tuotosta. Esimerkiksi Laven \& Wengerin (1991) mukaan oppimista tulisi tarkastella tilanteeseen sidotusta toiminnasta käsin. Oppimista ei tällöin nähdä pelkästään tiedon lisääntymisenä, vaan prosessina, jonka ansiosta oppija tulee tietyn yhteisön täysivaltaiseksi jäseneksi ja kykeneväksi kommunikoimaan yhteisön muiden jäsenten kanssa. Emme opi ainoastaan sisältöjä, vaan myös tiettyjä kulttuurisia ja sosiaalisia tapoja toimia. Yhteisöllisyys on alettu yhä enemmän ottaa huomioon myös työpaikkakoulutuksen suunnittelussa, jossa perinteisten yksilöön kohdistuvien koulutuksellisten ratkaisujen rinnalla painotetaan myös jatkuvaa ja yhteisöllistä, koko organisaation tasolla tapahtuvaa oppimista (esim. Launis \& Engeström 1999).

$\mathrm{M}$ uutamissa laajoissa viimeaikaisissa surveytutkimuksissa on selvitetty eri alojen työntekijöiden käsityksiä työssä oppimisesta, nykyisten työtehtävien edellyttämästä asiantuntijuudesta sekä oppimiseen vaikuttavista tekijöistä. Esimerkiksi Eraut'n (1998) tutkimuksen mukaan suuri osa oppimisesta työpaikalla tapahtuu informaalisti ilman erityistä suunnittelua tai määritystä siitä, mitä kulloinkin tulisi oppia. Oppiminen nousee luonnostaan työn vaatimuksista ja haasteellisuudesta esimerkiksi ratkaisemalla ongelmia, kiinnittämällä huomiota laadun tai tuottavuuden parantamiseen, selviytymällä muutoksista ja sosiaalisessa vuorovaikutuksessa työtovereiden ja asiakkaiden kanssa. Työ itsessään antaa mahdollisuuden eräänlaiseen kokemukselliseen oppimiseen, jota on vaikea kuvailla. Tutkimus osoitti myös, että vain pieni osa työssä oppimisesta tapahtuu formaalin koulutuksen ja harjoittelun välityksellä (ks. myös Darrah 1995). Työn ja työssä oppimisen sosiaalinen ulottuvuus tuli myös korostuneesti esille. Ongelmalliset tilanteet halutaan jakaa kollegojen kanssa, ja kokeneen kollegan toiminnan seuraaminen voi toimia oppimisen lähteenä, samoin kuin muiden kouluttaminen ja opastaminen. Jatkuva sosiaalinen tuki ja vuorovaikutus kollegojen kesken myös edesauttaa työn mielekkääksi kokemista (Tracey ym. 1995).

Gerberin (1998; Gerber ym. 1995) asiakaspalvelutyötä koskevassa tutkimuksessa työntekijät korostivat sitä, että päivittäisiä tehtäviä leimaa kiireellisyys ja kompleksisuus, asiakkaiden ongelmat ovat vaikeasti hahmotettavia eikä yhtä standardiratkaisua ongelmiin ole olemassa. Työn vaatimiin ongelmanratkaisutilanteisiin tulee vastata nopeasti ja työntekijöiden kokemuksen mukaan päätöksiä tehdään usein intuition varassa. Kokemusten arviointi tapahtuu usein vasta sitten kun "vahinko on jo tapahtunut" ja sitten kun kokemusten arviointiin ja reflektointiin on aikaa. Niinpä työntekijät kokivatkin, että yrityksen ja erehdyksen kautta oppiminen on eräs tärkeimmistä tavoista oppia työssä. Myös oppiminen työn suunnittelun sekä laadun varmistuksen yhteydessä on todettu hedelmälliseksi siksi, että uutta luovassa tilanteessa on arvioitava kriittisesti aikaisempaa kokemusta ja hahmotettava kokonaisuuksia tietoisemmalla tasolla (Orr 1996; Torraco 1999).

Työssä oppimista koskevat tutkimustulokset antavat aihetta pohtia koulutusorganisaatioiden roolia ja henkilöstökoulutuksen merkitystä tilanteessa, jossa formaali koulutus ei näyttäisi pystyvän vastaamaan työntekijöiden tarpeisiin. Valkeavaaran (1999) mukaan työtä oppimisympäristönä tulisi pystyä muokkaamaan yksilöllisesti siten, että se parhaiten palvelee yksittäisen työntekijän tarpeita ja työssä oppiminen integroituu muihin elämän konteksteihin sekä organisaation että yksilön kannalta mielekkäällä tavalla. Työn 
ja oppimisen yhdistäminen edellyttääkin tavoitteita, jotka kytkeytyvät työhön itseensä eikä kontekstista irrallaan oleviin osaamistavoitteisiin (Torraco 1999). Tämä puolestaan edellyttää työn ja työtehtävien analysointia. Myös ammattitaitoisten kollegojen rooli esimerkiksi työpaikkakouluttajina ja mentoreina tulee korostumaan, sillä kollegat ovat yksi osa sitä kontekstia, jossa työssä oppimista tapahtuu. Lisäksi yhteisen tietoisuuden tai ymmärryksen kehittyminen työpaikoilla on merkityksellistä siksi, että työntekijän on hyvä nähdä oma kantansa asioihin sinänsä, mutta myös yhtenä osana jotain laajempaa kokonaisuutta.

Työssä tapahtuva oppiminen kytkeytyykin toisaalta erityisiin työssä tarvittaviin taitoihin ja toisaalta organisaation kulttuuriin sekä organisaation sosiaalisiin verkostoihin. Työpaikka on käytännön yhteisö, jossa oppiminen ja asiantuntijuuden kehittyminen tapahtuu osallistumisen prosessina (Wenger 1998). Keskeistä tässä prosessissa on kehittyä hyväksi työntekijäksi motivoituneena ja saamalla mahdollisuuksia uusien asioiden kokeiluun ilman rangaistuksen pelkoa (Brown \& Duguid 1991; Schein 1993). Tiivistäen työntekijöiden oppimista työssä voisi luonnehtia ongelmakeskeiseksi ja kontekstisidonnaiseksi informaaliksi oppimiseksi.

\section{ASIANTUNTEMUS JA SEN KEHITTYMINEN: avainkysymyksenä teorian ja käytännön kytkentä}

$\mathrm{T}$ yössä oppimisen tavoitteena voidaan pitää asiantuntijuuden kehittymistä. Mitä sitten on asiantuntijuus? Yksiselitteistä vastausta ei ole, vaan vastauksen laatu riippuu siitä, minkälaisesta näkökulmasta kysymystä katsotaan. Asiantuntijuutta voidaan tarkastella esimerkiksi professionaalisena toimintana, jolle on ominaista sosiaalinen legitimointi, valtuutus tiettyihin työtehtäviin (esim. Eräsaari 1997; Konttinen 1997), tai sitä voidaan kuvata täysivaltaisena osallistumisena tietyn käytännön yhteisön toimintaan (Lave \& Wenger 1991) tai yksilöiden ja ryhmien asteittain etenevänä, progressiivisena ongelmanratkai- suprosessina, jossa yhä uudelleen määritellään tehtäviä ja toimintaa (Bereiter \& Scardamalia 1993). Tässä yhteydessä tarkastelemme asiantuntijuutta ja sen kehittymistä viimeksi mainitusta näkökulmasta käsin eli jatkuvana ongelmanratkaisutoimintana. Näin määriteltynä asiantuntijuuden keskeisinä komponentteina voidaan pitää teoriaa, käytännöllistä tietoa ja taitoja sekä itsesäätelytaitoja (Bereiter \& Scardamalia 1993; Eraut 1994; Eteläpelto \& Light 1999). Teoreettinen tieto on luonteeltaan yleispätevää ja formaalia, muodollista tietoa, ja se on hyvin eksplisiittistä. Käytännöllinen tieto sen sijaan koskee yksittäistapauksia ja on luonteeltaan usein intuitiivista ja "äänetöntä” (tacit knowledge). Itsesäätelytaidot liittyvät asiantuntijan metakognitiivisiin ja reflektiivisiin tietoihin ja taitoihin, eli oman ajattelun, oppimisen ja toiminnan tietoiseen ja kriittiseen tarkasteluun. Korkeatasoiselle asiantuntijuudelle on ominaista näiden eri komponenttien syvällinen integraatio, mikä merkitsee teorian, käytännön ja toiminnan itsesäätelyn joustavuutta toiminnassa (Bereiter \& Scardamalia 1993; ks myös Järvinen ym. 2000, 71-75).

Jos teorian, käytännön ja itsesäätelytaitojen integraatio on keskeistä asiantuntijuudessa, koulutuksellisesti merkittäväksi kysymykseksi muodostuukin se, miten tämä asiantuntijuuden osatekijöiden integroituminen tapahtuu ja miten sitä voidaan pedagogisin keinoin edistää. Oppimisen tutkijat ovat esittäneet tähän kysymykseen monenlaisia, mutta keskenään varsin samantapaisia vastauksia. Esimerkiksi Boshuizen työtovereineen (1995) kuvaa eksperttiyden kehittymistä tiedon kapseloitumisen prosessina, jossa opiskelijoiden omaksumat yksityiskohtaiset käsitteet hiljalleen korvautuvat yleisemmän tason käsitteillä, jotka tietyllä tavalla tiivistävät aikaisemmat käsitteet. Tiedon kapseloituminen on seurausta tiedon jatkuvasta soveltamisesta käytännön ongelmien ratkaisemiseen. Myös Bereiter ja Scardamalia (1993) korostavat ongelmanratkaisun merkitystä asiantuntijatiedon muodostumisessa. Ongelmanratkaisu on siis välittävä tekijä eksperttitiedon eri komponenttien integroitumisessa. Samoin Leinhardt kollegoineen (1995) korostaa sitä, että opiskelijoiden tulisi käyttää teo- 
reettista tietoa käytännöllisten ongelmien ratkaisuissa ja vastaavasti hyödyntää kokemuksen kautta hankittua käytännöllistä tietoa teoreettisten periaatteiden, hypoteesien ja käsitteellisten mallien rakentamiseen. Kokemuksellisen oppimisen teoreetikot viittaavat samaan prosessiin korostamalla reflektion merkitystä; oppiminen tapahtuu kokemusten, reflektion, käsitteellistämisen ja kokeilemisen kautta (Kolb 1984; Schön 1983;1987). Kaikille näille lähestymistavoille on yhteistä teorian ja käytännön vuorovaikutus ja integrointi ja sen kytkeminen henkilökohtaiseen pohdiskeluun, reflektointiin.

Kun työssä oppimisen ja työn kautta oppimisen erilaisia muotoja kehitetään koulutusjärjestelmän osaksi, vaarana on, että teoriaa ja käytäntöä aletaan entisestäänkin eriyttää toisistaan; koulutuksessa tapahtuva oppiminen saatetaan kokea yhä enemmän teorian pänttäämiseksi, työssä oppimisjaksot "todellisen" ammattitaidon kehittämisen vaiheeksi. Niinpä koulutukseen kytkeytyvän työssä oppimisen muotoja kehitettäessä onkin ensiarvoisen tärkeää, että tällaista eriyttämistä ei pääse syntymään, vaan että työn teoreettinen pohdiskelu ja työkokemusten reflektointi muodostuvat olennaiseksi osaksi työssä oppimista. Koulutuksen ja työn yhdistämisen pedagoginen avainkysymys onkin se, miten muodostetaan kiinteä yhteys teorian ja käytännön välille. Lisäksi tähän tulee kytkeä itsesäätelytaitojen eli metakognitiivisten ja reflektiivisten taitojen kehittäminen. Opettajien ja kouluttajien haasteena onkin ohjata erilaisia työn kautta oppimisen muotoja siten, että opiskelijat joutuvat käsitteellistämään ja reflektoimaan työkokemuksiaan ja tarkastelemaan niitä teoreettisen tiedon valossa ja vastaavasti tarkastelemaan teoreettista tietoa käytännön työn valossa. Välineinä tällaiseen reflektointiin voidaan käyttää esimerkiksi oppimispäiväkirjoja ja ryhmäkeskusteluja (esim. Cooper 1998; Dunlap 1998; Lyons 1999).

\section{MITEN TYÖSSÄ OPPIMINEN JA KOULUOPPIMINEN EROAVAT?}

os halutaan antaa lyhyt ja yksinkertainen vas-
taus kysymykseen, miten työssä oppiminen ja kouluoppiminen eroavat toisistaan, vastaus voisi olla "eivät mitenkään". Tarkastellaanpa oppimista sitten kognitiivisina tiedon hankinnan prosesseina tai osallistumisena yhteisön toimintaan (ks. Sfard, 1998) itse oppimisen prosessit ovat luonteeltaan samanlaista riippumatta siitä, missä ne tapahtuvat. Sekä työssä että koulutuksessa oppijan kognitiiviset mekanismit toimivat samalla tavoin ja molemmissa ympäristöissä oppijat sosiaalistuvat yhteisönsä käytäntöihin. Koulu ja työpaikka ovat kuitenkin erilaisia konteksteja oppimiselle ja niillä on erilaiset tavoitteensa, toimijansa ja traditionsa. Koulussa tapahtuvan oppimisen ja työssä oppimisen eroja on tarkasteltu mm. tiedon rakenteellisten erojen näkökulmasta. Mm. Resnickin (1987) tunnetun analyysin mukaan kouluoppimisen päämääränä on yleistieto ja yleiset taidot, kun koulun ulkopuolella tarvitaan tilannesidonnaista tietoa ja osaamista. Koulussa arvostetaan abstraktia ajattelua ja puhdasta mentaalista toimintaa, mutta koulun ulkopuolinen toiminta on kontekstisidonnaista, ja ongelmallisiin käytännön tilanteisiin voidaan hakea ratkaisua apuvälinein. Lisäksi toimiminen koulussa perustuu yksilöllisiin saavutuksiin, kun taas koulun ulkopuolinen toiminta on usein sosiaalisesti jaettua. Kouluoppimisen ja työssäoppimisen ero onkin lähinnä ero kahden erilaisen kulttuurin välillä. Laven ja Wengerin (1999) mukaan koululle onkin tyypillistä "toistavan toiminnan kulttuuri", jollaista ei muualla elämässä juurikaan esiinny.

$\mathrm{T}$ yössä oppimista luonnehtii selkeä kontekstisidonnaisuus, kun taas kouluopetus on perinteisesti lähtenyt vahvasti siitä oletuksesta, että tieto ja oppiminen voisi olla kontekstista riippumatonta. Opiskelu ja koulu, työ tai vaikkapa harrastukset ovat kuitenkin toisistaan poikkeavia oppimisen konteksteja, joissa on tietynlaiset tehtävät ja sosiaalinen todellisuus, jossa toimitaan. Kussakin kontekstissa ihmiset muodostavat vuorovaikutuksessa yhteisiä merkityksiä toiminnasta, esim. osaamisesta tai oppimisesta (ks. Billet 1998; Henriksson 1999; Sandberg 1994; 2000; ks. myös Kivinen \& Silvennoinen 1999). Osaaminen nähdäänkin nykyisin laajemmin kuin pelkkänä tietojen ja taitojen erotteluna. Mm. Rantalaihon (1994) mukaan osaaminen liittyy aina johonkin tekemiseen, mutta on laajemmas- 
sa mielessä näkymätöntä. Osaamisen nähdään suhteutuvan työhön, tilanteisiin ja toimintaympäristöön, joissa se tapahtuu ja eri työtehtävissä edellytettävä osaaminen muotoutuu työntekijöiden sille antaman merkityksen välittämänä (Ellström 1997; Sandberg 2000). Siksi erilaisten määritysten ja käsitysten siirtäminen kontekstista toiseen on vaikeaa ellei jopa mahdotonta.

$\mathrm{E}$ ngeström (1991) on analysoinut kolmea eriaista teoreettista näkökulmaa ratkaisuna kouluoppimisen eristäytymiseen "todellisesta elämästä”, Davydovin oppimisteoriaa, Laven ja Wengerin situated learning -näkökulmaa sekä Engeströmin omaa ekspansiivisen oppimisen ideaa. Dadydovin ratkaisussa oppilaita ohjataan sellaisen teoreettisen ajattelun kehittämiseen, jota voidaan soveltaa myös koulun ulkopuolella siirtymällä abstraktilta tasolta konkreettiselle. Laven ja Wengerin ratkaisu sen sijaan olisi luoda koulun sisälle aitoja käytännön yhteisöjä tai ehkä korvata kouluoppimista osallistumalla tällaisten yhteisöjen toimintaan koulun ulkopuolella. (Työssä oppimisen jaksojen voidaan nähdä edustavan tällaista ajattelua). Ekspansiivisen oppimisen lähestymistapa ratkaisisi koulun eristäytymisen laajentamalla asteittain oppimisen kohdetta ja kontekstia, jolloin siirryttäisiin pois oppikirjojen sisältöjen toistamisesta niiden kriittiseen analyysiin sekä keksimiseen ja soveltamiseen.

$\mathrm{V}$ aikka kouluoppimisen ja työssä oppimisen kulttuurit selkeästi eroavat toisistaan, voidaan ajatella että niiden väliset erot ovat hiljalleen muuttumassa ja kaventumassa. Tähän on lähinnä kaksi syytä, ensinnäkin tietoyhteiskuntakehitys ja sen mukanaan tuoma symbolianalyyttisten ammattien lisääntyminen ja toiseksi uudenlaisten, autenttisuuteen pyrkivien pedagogisten ratkaisujen käyttöönotto koulutuksessa. Reichin (1991) mukaan tietoyhteiskunnalle tyypillisissä symbolianalyyttisissa tehtävissä abstraktin ajattelun merkitys on tärkeä. Pelkkä kontekstiin sidottu päättely ei riitä, vaan tarvitaan kykyä nähdä kokonaisuuksia, analysoida ja syntetisoida suuria tietomääriä, ymmärtää laajoja prosesseja ja tehdä yleistyksiä. ${ }^{2}$ Näin ollen kouluoppimisessa korostettu käsitteellisellä tasolla tapahtuva päättely ja abstrahointi onkin itse asiassa oleellista tämän päivän yhteiskunnan avainammateissa, ja tällaisissa työtehtävissä oppimiseen liittyy silloin kouluoppimiselle tyypillistä abstrahointia ja yleistämistä. Vastaavasti uudenlaisissa oppimismalleissa, esimerkiksi työelämään suuntautuvassa projektiopiskelussa tai ongelmalähtöisessä oppimisessa, on monia piirteitä, jotka simuloivat aitoja työelämän ongelmanratkaisutilanteita tai jopa perustuvat niihin.

\section{ERILAISIA NÄKEMYKSIÄ KOULUTUKSEN JA TYÖN INTEGROINNISTA}

\section{$\mathrm{K}$} oulutuksen ja työn yhdistäminen ei suinkaan ole ongelmatonta, vaan siihen liittyy monia problemaattisia kysymyksiä. Ensinnäkin jo itse kysymys työssä oppimisen perimmäisestä tarkoituksesta voi saada erilaisia tulkintoja. Hagerin (1998) mukaan näkemykset työssä oppimisesta eroavat sen mukaan, pidetäänkö ensisijaisena tavoitteena 1) oppijan yksilöllistä kasvua ja kehitystä vai 2) inhimillisen pääoman kehittämistä ja hyödyntämistä kukoistavan elinkeinoelämän tarpeisiin. Onko siis oppiminen tarkoitettu työelämän tarpeisiin vai työ oppimisen tarpeisiin? Epäilemättä näiden tavoitteiden ei välttämättä tarvitse olla ristiriidassa keskenään, mutta Hagerin mukaan rajallisten resurssien maailmassa on todennäköistä, että arvokonflikteja syntyy.

Toinen työssä oppimisen etiikkaan liittyvä kysymys kytkeytyy oppimisen kahdenlaisiin funktioihin: oppimisen tavoitteena voi olla toisaalta tiettyihin käytäntöihin sosiaalistuminen, toisaalta olemassa olevien käytäntöjen muuttaminen, uuden tuottaminen. Jarvis (1992) puhuukin oppimisen paradokseista; oppiminen voi olla innovatiivista ja luovaa tai se voi olla sopeutuvaa ja reproduktiivista. Erilaisia työssä oppimisen muotoja voidaankin arvioida suhteessa siihen, missä määrin ne tukevat sosiaalistamista, missä määrin emansipaatioita tai innovatiivisuutta. Esimerkiksi perinteinen oppisopimustyyppinen koulutus (apprenticeship) näyttäisi kytkeytyvän pikemminkin entisten käytäntöjen reprodusoimiseen, kun sen sijaan esimerkiksi yritysten toi- 
meksiantamat projektityyppiset opiskelijatyöt, joissa etsitään uusia ratkaisuja tiettyihin ongelmiin, edustavat innovaatiohakuisuutta. Viimeksi mainittua edustaa työelämän puolella myös mm. Virkkusen ym (1997) kuvaama muutoslaboratorio-menetelmä, jossa analysoidaan työtoimintaa ja kehitetään työkäytäntöjä. Erilaisia työssä oppimisen muotoja ei ole kuitenkaan syytä tällä tavalla luokittaa joko säilyttäviksi tai innovatiivisiksi, vaan erilaisissa toteutustavoissa voivat nämä molemmat näkökulmat olla läsnä. Vaikka tavoitteena olisikin luoda jotain uutta, voidaan samanaikaisesti säilyttää jotain entisellään. Innovatiivisuuden tai uudenlaisen ajattelutavan ja toiminnan tuottamisen kannalta olennaisena voidaan pitää kriittistä reflektiota tai uudistavaa oppimista (mm. Schön 1983; Jarvis 1992; Mezirow ym. 1996), jolloin toimintaa tai omien viitekehysten taustaoletuksia arvioidaan ja muutetaan.

$\mathrm{E}$ rilaisia käsityksiä on olemassa myös siitä, mitä yöpaikka on oppimisympäristö. Candy ja Mathews (1998) ovat identifioineet tästä viisi erilaista näkemystä. Ensimmäiselle näkemykselle on ominaista, että työpaikalla harjoittelun nähdään edustavan yhtä formaalin koulutuksen osaa, jossa tieto siirtyy 'ylhäältä alas', eksperteiltä noviiseille. Toisen näkemyksen mukaan työpaikka on vuorovaikutuksen ja ongelmanratkaisun tila, jossa ihmisten on opittava ymmärtämään työn perusperiaatteita pikemmin kuin oppimaan standardirutiineja. Tässä näkemyksessä painotetaan tiimityön kautta tapahtuvaa ongelmanratkaisua ja reflektiivistä ammattikäytäntöä. Kolmannen näkemyksen mukaan työpaikka on tiedon jakamisen ja tiedon luomisen paikka. Oppiminen ja työ integroituvat uuden tiedon luomisessa ja tieto nähdään sosiaalisesti konstruoituneena. Neljännen näkemyksen mukaan työpaikka on osa globaalia tietoyhteiskuntaa. Tärkeää tietoa virtaa jatkuvasti organisaatioon, jossa se on nopeasti käsiteltävä ja hyödynnettävä. Ammatinharjoittajat, jotka voivat olla jossain kontekstissa kilpailijoita keskenään, ovat yhteistyössä jollain toisella alueella muodostaen eräänlaisia rajoja ylittäviä oppimisyhteisöjä. Viides käsitys työpaikasta oppimisympäristönä kuvaa työpaikkaa oppivana organisaationa, jossa yksilöt, tiimit ja koko yri- tys oppivat jatkuvasti alati muuttuvissa konteksteissaan. Tähän näkemykseen liittyy käsitteellinen muutos koulutuksen ja käytännön harjoittelun dikotomisoinnista kohti integroidumpaa käsitettä jatkuvasta asiantuntijuuden kehittymisestä ja elinikäisestä oppimisesta.

Edellä kuvatut käsitykset työpaikasta oppimisympäristönä eivät luonnollisesti ole toisiaan poissulkevia, vaan voivat olla limittäisiä tai esiintyä erilaisina kombinaatioina. Ne edustavat myös historiallista jatkumoa, jossa ensin mainitut käsitykset alkavat itsenäisinä näkemyksinä olla ohitettuja, kun taas jäljempänä mainitut edustavat uudempaa ajattelutapaa. Kuitenkaan näkemyksiä ei ole syytä arvottaa siten, että toiset olisivat 'parempia' kuin toiset, vaan jokaisella näkemyksellä on paikkansa ilmiön ymmärtämiseksi (Candy \& Mathews 1998).

Käsitykset työssä oppimisesta vaihtelevat myös opettajien keskuudessa. Toiset opettajat ajattelevat, että työharjoittelussa opiskelija oppii yksinkertaisesti olemalla työpaikalla, kokoamalla tietoja ja harjoittelemalla taitoja. Toiset opettajat taas pitävät tärkeänä oppitunneilla opetetun teorian kytkemistä käytännön työhön ja teorian uudelleen tulkintaa työkokemuksen valossa. Lisäksi jotkut opettajat painottavat opiskelijan, ohjaajan ja työnantajan yhteistyötä sekä työtehtävien suunnittelussa että kokemusten tulkinnassa. (Martin 1998; ks. myös Lasonen 1999). Martinin mukaan on todennäköistä, että opettajien erilaisilla käsityksillä on yhteyttä opiskelijoiden työssä oppimisen laatuun. Ainakin voidaan olettaa, että työssä oppimisen jaksot muodostuvat hyvin erilaisiksi sen mukaan, nähdäänkö ne vain opiskelijan irralliseksi tiedonkokoamisjaksoksi vai pyritäänkö niihin aktiivisesti kytkemään teoriaa, sen tulkintaa ja kaikkien osapuolten yhteistä työskentelyä.

$\mathrm{K}$ oulutuksen ja työelämän välistä yhteistyötä a opiskelijoiden työssä oppimista käsiteltäessä on harvemmin nostettu esiin yhteistyön ongelmallisia puolia tai kriittisiä näkökulmia. Hughes (1998) onkin kritisoinut asiaa koskevaa keskustelua siitä, että aikuisen oppimista ja työssä oppimista koskevat mallit olettavat niiden so- 
veltuvan kaikenlaisiin työympäristöihin ja että niissä ei yleensä oteta huomioon mahdollisuutta, että opiskelija voi joutua olosuhteisiin, joissa häneen suhtaudutaan negatiivisesti. Kuitenkin tutkimukset työssä oppimisesta hänen mukaansa osoittavat, että työpaikka voi olla kaukana ihanteellisesta oppimisympäristöstä. Vakinaisten työntekijöiden ja opiskelijoiden intressit saattavat olla ristiriidassa. Työntekijät saattavat olla esimerkiksi niin kiireisiä, ettei heille jää riittävästi aikaa uuden tulokkaan ohjaukseen. Samoin työntekijöiden ja opiskelijoiden intressit ovat erilaiset kuin työnantajien. Hughes esittääkin, että erityistä huomiota tarvitaan molemminpuolisen luottamuksen kehittämiseen ja sen tutkimiseen, minkä tyyppistä oppimista työssä itse asiassa voidaan saada aikaan.

\section{PEDAGOGISIA RATKAISUJA TYÖN JA KOULUTUKSEN LÄHENTÄMISEKSI}

Perinteisessä koulutusmallissa, joka perustui pitkälti teorian ja käytännön kahtiajakoon, oletuksena oli, että opiskelijoiden on ensin omaksuttava alansa perusteoria, ennen kuin he voivat päästä käytännön kentälle harjoittelemaan taitojaan. Harjoittelu onkin perinteisissä opetussuunnitelmissa yleensä sijoittunut opiskelun loppuvaiheeseen. Nykypäivän näkemys asiantuntijaksi oppimisesta sen sijaan painottaa, että tiedon oppiminen ja tiedon käyttäminen eivät ole erillisiä prosesseja, vaan ne ovat yhtä ja samaa prosessia, oppiminen on tilannesidonnaista ja sitä tapahtuu työssä ja työn kautta osallistumalla aitoihin toimintakäytäntöihin (Brown ym. 1989; Eraut 1994; Eraut ym. 1998; Lave \& Wenger 1991; Resnick 1987). Niinpä nykyisin suositellaankin sellaisia pedagogisia järjestelyjä, joissa opiskelijat kohtaavat todellisen elämän ongelmat jo opiskelun alkuvaiheissa ja opiskelevat teoriaa kytkettynä näihin arkielämän ongelmiin (esim. Leinhardt ym. 1995; Eteläpelto, 1998). Tällaisen opiskelun mahdollistaa esimerkiksi ongelmalähtöinen oppiminen (problem-based learning; ks. esim. Boud \& Feletti, 1991; Harland, 1998; Poikela, 1998), jossa opetus ei rakennu oppiainekohtaisesti, vaan käytännöllisistä ongel- mista käsin. Samantapainen pedagoginen ratkaisu on projektioppiminen, jossa opiskelijaryhmät tekevät etukäteen määritellyn aikataulun puitteissa jonkin projektityön (esim. Askeland, 1997; Blumenfeld ym., 1991; Sexton, 1990). Aidoimmillaan tämä työ tehdään todelliselle asiakasyritykselle (esim. Eteläpelto \& Tourunen 1999). Toisenlaisen lähtökohdan työn ja koulutuksen kytkemiselle on tarjonnut oppisopimuskoulutus, jossa koulutus tapahtuu pääsääntöisesti työpaikalla sisältäen mahdollisesti joitakin lyhyempiä oppilaitoksessa opiskeltavia jaksoja. Suomessa oppisopimuskoulutus ei kuitenkaan ole ollut yhtä laajaa kuin esimerkiksi Saksassa (Kivinen \& Peltomäki 1999).

Opiskelijoiden osallistumista työelämään osana koulutustaan voidaan eritellä sen mukaan, onko tarkoituksena valmentaa opiskelijoita vain niihin työtehtäviin tai ammatteihin, joissa heidän työssä oppimisensa tapahtuu vai onko tarkoituksena kehittää yleisiä työelämässä tarvittavia tietoja ja taitoja ilman valmentamista tiettyyn ammattiin. Stern kollegoineen (1998) on nimittänyt tiettyyn ammattiin valmentavaa työssä oppimista learn and stay -malliksi ja vastaavasti yleisiä valmiuksia antavaa työssä oppimista learn and go -malliksi. Molempia työssä oppimisen muotoja voidaan toteuttaa joko koulun ulkopuolella tai oppilaitosten itsensä ylläpitämissä yrityksissä. Koulun ulkopuolista learn and stay -mallin mukaista työssä oppimista edustaa esimerkiksi oppisopimus-tyyppinen (apprenticeship) koulutus tai Yhdysvalloissa keskiasteella sovellettu cooperative education (co-op), jonka puitteissa opiskelijat suorittavat tiettyjä kursseja harjoittelemalla yrityksissä. Learn and stay -malli toteutettuna oppilaitoksen omissa yrityksissä on tavallinen ammatillisessa koulutuksessa. Esimerkiksi Yhdysvalloissa noin viidenneksellä keskiasteen kouluista on yritys, jossa opiskelijat tuottavat tuotteita tai palveluja osana opiskeluaan (Stern ym. 1998). Myös Suomessa ammatilliset oppilaitokset ovat perinteisesti ylläpitäneet esimerkiksi ravintoloita, autokorjaamoja tai kampaamoja. Yliopistotasolla opetusharjoittelusta vastaavat normaalikoulut tai yliopistolliset sairaalat edustavat oppilaitoksen sisäistä työssä oppimisen learn and stay mallia. 
Oppilaitosten ylläpitämät yritykset voivat tarjota työssä oppimisen jaksoja myös opiskelijoille, jotka eivät ole erikoistumassa tietylle alalle tai tiettyyn ammattiin. Tällaista learn and go -tyyppistä mallia edustaa esimerkiksi Yhdysvalloissa Junior Achievement -ohjelma, jonka puitteissa opiskelijat keräävät ensin varoja alkupääomaan ja perustavat sitten miniyrityksiä, joissa he tuottavat ja myyvät jotain tiettyä tuotetta. Britanniassa vastaava ohjelmaa on nimeltään Young Enterprise ja sen piiriin kuuluu 40 prosenttia keskiasteen kouluista. Tanskaan on perustettu tuotannollisia keskiasteen kouluja, jotka on tarkoitettu työttömille nuorille joilla ei ole ammatillista tutkintoa. Näissä kouluissa yleissivistävien ja ammatillisten aineiden opetus kytketään tiettyjen kulutushyödykkeiden (esim. vaatteiden tai huonekalujen) tuottamiseen ja myymiseen. Tarkoitus ei ole valmentaa opiskelijoita tiettyyn ammattiin, vaan vahvistaa perustaitoja ja tarjota työkokemusta. Työelämän puolella tapahtuvaa Learn and go -mallin mukaista työssä oppimista ovat esimerkiksi suomalaisten peruskoulujen tai lukioiden työelämään tutustumisjaksot, jotka vaihtelevat pituudeltaan muutamasta päivästä muutamaan viikkoon. Samanlaisia järjestelyjä on myös monissa muissa maissa. Tavoitteena on antaa ensimmäinen kosketus työelämään ja mahdollisesti aineksia tulevaa alan valintaa varten, vaikka tarkoitus ei olekaan tietyn ammattityön harjoitteleminen.

A ikaisemmille koulutusjärjestelmään kytketyille yössä oppimisen muodoille oli tyypillistä se, että oppiminen oli pitkälti oppilaitoksesta käsin kontrolloitua ja tavoitteet tarkkaan etukäteen määriteltyjä - ja pikemminkin opettajien kuin opiskelijoiden määrittelemiä. Nykyisin suuntaus on kohti sellaisia oppimisen muotoja, joissa kolme tasavertaista partneria eli opiskelija (tai opiskelijaryhmä), oppilaitos ja työnantaja yhdessä sopivat oppimisen tavoitteista ja sisällöistä. Usein kyse on projektityöstä, jonka opiskelijat tekevät yritykselle oppilaitoksen ja yrityksen ohjaamina (Foster \& Stephenson 1998). Tällaiselle työn kautta oppimiselle on tyypillistä, että vastuu jaetaan eri osapuolten kesken, mutta opiskelijoilla on avainrooli omien tavoitteidensa ja tarpeidensa määrittelyssä. Opiskelijalähtöinen työssä oppiminen asettaa monenlaisia haasteita oppilaitoksille, esimerkiksi sopivien oppimisympäristöjen määrittelylle, akateemisen henkilöstön rooleille, resurssien jakamiselle, oppimisen kontrollille ja suoritusten tason valvomiselle. Perinteinen järjestelmä, jossa oppilaitoksessa määriteltiin oppimistavoitteet tarkasti etukäteen oppiainerajojen mukaisesti, ei toimi tilanteissa, joissa oppimisen sisällöt ja menetelmät johdetaan projektien ja työnantajien tarpeista käsin. Foster ja Stephenson (1998) korostavatkin, että ihanteellisessa tilanteessa työhön perustuva oppiminen on ongelmakeskeistä, itseohjautuvaa tiimityötä, jossa pyritään parantamaan yrityksen saavutuksia ja tuottamaan innovaatioita.

\section{TUTKIMUKSELLISIA HAASTEITA}

$\mathrm{L}$ isääntyvä yhteistyö koulutuksen ja työelämän älillä ja uudenlaiset työssä oppimisen muodot tulevat epäilemättä muuttamaan oppimisen luonnetta ja luomaan uudenlaisia oppimismahdollisuuksia. Nyt tarvitaankin sekä käsitteellistä että kontekstuaalista tutkimuksellista tietoa työhön liittyvistä oppimisprosesseista ja oppimisympäristöistä koulutuksen ja työn kohdatessa. Työssä tapahtuvan oppimisen ilmiöön, sen prosesseihin ja työn konteksteihin pureutuvalle tutkimukselle on tarvetta, sillä tarkastelemalla työelämässä tapahtuvaa oppimista voidaan kehittää sekä uusia työssä oppimisen muotoja että luoda formaalin koulutuksen käyttöön oppimisympäristöjä, jotka valmistavat opiskelijoita paremmin nopeasti muuttuvan työelämän aktiivisiksi toimijoiksi. (ks. myös Boud ym. 1998.)

Oppimisen tutkimuksen ja oppimisnäkemysten perussuuntauksia on kuvattu kahdella metaforalla, omaksumismetaforalla (acquisition) ja osallistumismetaforalla (participation) (Sfard 1998). Omaksumismetaforassa oppiminen nähdään perinteiseen tapaan tiedon hankkimisena ja 'omistamisena', kun taas osallistumismetafora kuvaa oppimista tietynlaiseen toimintakulttuuriin osalliseksi tulemisena. Mielestämme työssä oppimisen tutkimuksessa näiden molempien näkökulmien läsnäolo on välttämätön, jotta työssä oppimisen prosesseja voitaisiin ymmärtää riittävän 
monipuolisesti. On selvää, että oppimisen kuvaaminen esimerkiksi pelkästään yksilön kognitiivisten rakenteiden kehittymisenä on liian kapea näkökulma, minkä vuoksi tarvitaan analyysia niistä sosiaalisista ja kulttuurisista käytännöistä ja toimintarakenteista, joissa oppiminen työelämässä ja koulutuksessa tapahtuu. Samalla oppiminen tulee nähdä toimintana, jossa nämä rakenteet muovautuvat ja edelleen kehittyvät. Tarvitaan tietoa siitä, miten työssä ylipäätään opitaan, millä tavalla työntekijät oppivat työpaikoillaan, miten opiskelijat oppivat koulutukseen liittyvässä työssä oppimisessa ja miten vakituiset työntekijät ja opiskelijat voivat yhdessä rakentaa uutta ymmärrystä.

Nykypäivän asiantuntijuudelle on tyypillistä kollaboratiivisuus. Ammatti-ihmiset työskentelevät työryhmissä ja tiimeissä, jakavat tietojaan ja taitojaan muiden saman alan ja eri alojen ammattilaisten kesken ja toimivat moniammatillisissa verkostoissa. Tiimityö, tiimioppiminen, kollaboratiivinen työ ja kollaboratiivinen oppiminen ovatkin tulleet sekä oppimisen välineiksi että oppimisen tavoitteiksi sekä työelämässä että koulutuksessa. Se, miten tietoa konstruoidaan ja jaetaan organisaatioissa ja tiimeissä on keskeistä organisaatioiden kehitykselle (Argyris \& Schön 1996; Nonaka 1994). Niinpä kollaboratiivisen oppimisen ja organisaatio-oppimisen tutkimuksessa dialogin, jaetun ymmärryksen ja jaetun asiantuntijuuden käsitteet ovat tulleet keskeisiksi (esim. Senge, 1990). Näkemyksemme mukaan näiden käsitteiden tulee olla keskeisiä myös koulutuksen ja työelämän välisen yhteistyön ja työssä oppimisen tutkimuksessa.

$\mathrm{K}$ aiken kaikkiaan koulutuksen ja työelämän västä vuorovaikutusta ja yhteistyötä sekä työssä oppimista on syytä tutkia ainakin neljästä näkökulmasta käsin: 1) oppimisen ja asiantuntijuuden kehittymisen kannalta, 2) oppilaitosten ja niiden henkilökunnan kannalta, 3) työelämän organisaatioiden ja työnantajien näkökulmasta sekä 4) koulutusjärjestelmän ja koko yhteiskunnan näkökulmasta. Tämä edellyttää monitieteistä ja monitasoista tutkimusta, jossa yhdistyvät yksilötason oppimispsykologinen näkökulma, sosiokulttuurinen lähestymistapa, aikuiskasvatuk- sen ja kouluoppimisen teoriat, pedagoginen kehittämistyö sekä yhteiskuntatieteellinen analyysi koulutuksen ja työelämän suhteista.

\section{JOHTOPÄ̈̈TÖKSIÄ: miten rajat voidaan ylittää?}

lemme tässä artikkelissamme käsitelleet koulutuksen ja työelämän yhteistyötä ja työssä oppimista pedagogisesta näkökulmasta. Totesimme koulun ja työn olevan varsin erilaisia konteksteja oppimiselle. Kun työssä oppimista luonnehtii informaalisuus, ongelmakeskeisyys, kokemuksellisuus, kontekstuaalisuus ja yhteisöllisyys, kouluoppiminen on perinteisesti ollut muodollista, yleistietoa ja abstraktia ajattelua painottavaa sekä yksilöllisiä suorituksia korostavaa.

Analyysissämme kuitenkin päädyimme siihen, että toisaalta tietoyhteiskuntakehitykseen liittyvä symbolianalyyttisen, merkityksiä luovan ja muokkaavan työn lisääntyminen ja toisaalta uudenlaisten autenttisuuteen ja yhteisöllisyyteen pyrkivien pedagogisten ratkaisujen yleistyminen tietyllä tavalla tuovat työssä oppimista ja kouluoppimista lähemmäksi toisiaan. Työssä oppimisen tavoitteena näimme asiantuntijuuden kehittymisen ja esitimme, että sen kannalta keskeistä on teorian, käytännön ja itsesäätelytaitojen kehittämisen integroiminen ja siihen liittyvä reflektiivinen pohdiskelu. Tällaista asiantuntijuuden kehittymistä voivat palvella monenlaiset koulutuksen ja työelämän yhteistyön ja työssä oppimisen muodot.

$\mathrm{M}$ onet Suomessa viime vuosina toteutetut koulutusuudistukset, kuten ammattikorkeakoulujen perustaminen, ammattitutkintojärjestelmän luominen, työssäoppimisjakson liittäminen ammatilliseen koulutukseen ja oppisopimuskoulutuksen laajeneminen ovat selkeitä merkkejä siitä, että koulutuksen ja työelämän välinen yhteistyö on meilläkin laajenemassa ja syvenemässä. Järjestelmätason uudistukset luovatkin pohjaa integraatiolle, mutta ne eivät yksin riitä. Lisäksi tarvitaan pedagogista kehittämistä, jossa työn ja oppimisen integroituminen voisi toteutua. Työssä oppimisjaksot eivät saisi jäädä 
muusta opetuksesta irrallisiksi, vaan työelämäkokemuksia tulisi reflektoida teorian valossa ja vastaavasti tarkastella teoriaa käytännön valossa.

Lisäksi formaaliin koulutukseen liittyen on peräänkuulutettu sellaisia kouluoppimisen muotoja, joissa työskenneltäisiin erilaisissa simuloiduissa työympäristöissä, hyödynnettäisiin erityisesti suunniteltuja vuorovaikutustilanteita ja paneuduttaisiin aitoon ongelmanratkaisuun (Mandl ym. 1996; Resnick 1987). Onnistuneet pedagogiset ratkaisut sisältävätkin koulun ulkopuolisen oppimisen piirteitä, sosiaalisesti jaettua ajattelutyötä ja yhdessä suoritettavia tehtäväkokonaisuuksia, joiden kautta hahmottuu koko tarvittavan osaamisen kokonaisuus. Tämä toteutuu esimerkiksi työelämäprojekteissa, ongelmalähtöisessä oppimisessa tai erilaisissa simulaatioissa, joissa työelämän organisaatiot voivat olla mukana (esimerkki viimeksimainitusta, ks. Miettinen ym. 1997). Tällaiset oppimisympäristöt rohkaisevat opiskelijoita merkityksenluontiin ja tulkintaan, mikä on usein kouluoppimisen puute. Tietoinen merkitysten rakentaminen ja tulkintojen tekemisen taito ovat Resnickin (1987) mukaan juuri niitä taitoja, joiden avulla selviydytään uusien ongelmatilanteiden vaatimasta tilanteiden arvioinnista ja analysoinnista.

$\mathrm{V}$ iimeaikaisissa tutkimuksissa on tultu yhä vahvemmin tietoiseksi siitä, että tilannesidonnaisuutta on vaikea ylittää ja se osaltaan määrittää oppimista. Työpaikat ovat sosiokulttuurisen käytännön määrittämiä alueita ja nämä käytännöt ovat hyvin erilaisia (Billet 1998). Työlle on ominaista uudet ja ennalta määrittämättömät ongelmat, joita ei voi ratkaista ennalta tiedossa olevien menettelytapojen avulla, vaan aina uudelleen tilanteeseen sopivalla, luovallakin tavalla. Tärkeäksi kysymykseksi työssä oppimisen kannalta nousee myös se, kuinka pitkälle tietyissä työtehtävissä tarvittavaa taitoa ja osaamista voidaan kuvata ja oppia etukäteen. Useissa töissä työtehtävien vaatimia toimintatapoja ja vaadittavaa ammattitaitoa on vaikea ennakoida. Yleisen teoreettisen tiedon ja kontekstiin sidotun ongelmanratkaisun toisiinsa kytkeminen onkin työhön liittyvän oppimisen avainkysymyksiä.

\section{Lähteet}

ARGYRIS, C. \& SCHÖN, D. A. (1996) Organizational learning II : theory, method and practice. Reading, MA: Addison-Wesley.

ASKELAND, K. (1997) Project organised learning - what is it 'really'? Paper presented at the International Conference on Project Work in University Studies. Roskilde, Denmark.Conference Papers Volume II, 163-174.

BEREITER, C., \& SCARDAMALIA, M. (1993) Surpassing ourselves: An inquiry into the nature of expertise. Chicago: Open Court.

BILLETT, S. (1998) Understanding workplace learning: Cognitive and sociocultural perspectives. Teoksessa D. Boud (Ed.) Current issues and new agendas in workplace learning. Springfield (Va.): NCVER, 47-68.

BOSHUIZEN, H. P. A., SCHMIDT, H.G., CUSTERS, E.J.F.M, \& VAN DE WIEL, M.W. (1995) Knowledge development and restructuring in the domain of medicine: The role of theory and practice. Learning and Instruction 5, 269-289.

BLUMENFELD, P.C., SOLOWAY, E., MARX, R.W., KRAJSIC, J.R., GUZDIAL, M \& PALICSAR, A. (1991) Motivating project-based learning: Sustaining the doing, supporting and learning. Educational Psychologist 26, 369-398.

BOUD, D. \& FELETTI, G. (1991) The challenge of problem-based learning. New York: St. Martin's Press.

BOUD, D., FREELAND, J., HAWKE, G., \& MCDONALD, R. (1998) More strategic, more critical, more evaluative: Perspectives on research into workplace learning and assessment. Teoksessa D. Boud (Ed.) Current issues and new agendas in workplace learning. Springfield (Va.): NCVER, 136-150.

BROMME, R., \& TILLEMA, H. (1995) Fusing experience and theory: the structure of professional knowledge. Learning and Instruction 5, 261-267.

BROWN, J. S., COLLINS, A. \& DUGUID, P. 1989 Situated cognition and the culture of learning. Educational Researcher 18 (1), 32-42.

BROWN, J. S. \& DUGUID, P.1991. Organizational Learning and Communities-of-Practice: Toward a Unified View of Working, Learning and Innovation. Organization Science 1 (2), 40-57.

CANDY, P., \& MATTHEWS, J. (1998) Fusing learning and work: Changing conceptions of workplace learning. Teoksessa D. Boud (Ed.) Current issues and new agendas in workplace learning. Springfield (Va.): NCVER, 9-30.

COOPER, D.D. (1998) Reading, writing, and reflection. Teoksessa R.A. Rhoads \& J.P.F. Howard (eds.) Academic service learning: A pedagogy of action and reflection. San Francisco: Jossey-Bass, 47-56.

DARRAH, C. (1995) Workplace training, workplace learning: a case study. Human Organization 54 (1), 31-41.

DUNLAP, M.R. (1998). Methods of supporting students' critical reflection in courses incorporating service learning. Teaching of Psychology 25 (3), 208-210.

ELLSTRÖM, P-E. (1997) Many meanings of Occupational Competence and Qualification. Teoksessa A. Braun (Ed.) Promoting vocational Education and Training: European Perspectives. Hämeenlinnan 
Opettajankoulutuslaitos. Ammattikasvatussarja $17,47-58$.

ENGESTRÖM, Y. (1991) Non Scolae Sed Vitae Discimus: Toward overcoming the Encapsulation of School Learning. Learning and Instruction 1,243259.

ENGESTRÖM, Y. (1995) Kehittävä työntutkimus. Perusteita, tuloksia ja haasteita. Helsinki: Painatuskeskus. Hallinnon kehittämiskeskus.

ERAUT, M. (1994) Developing professional knowledge and competence. London: Falmer Press.

ERAUT, M., ALDERTON, J., COLE, G. \& SENKER, P. (1998) Development of knowledge and skills in employment. Final report of research project funded by "the Learning Society" Programme of the Economic and Social Research Council. University of Sussex.

ERÄSAARI, R. (1997) Mistä asiantuntijuus on kotoisin? Teoksessa J. Kirjonen, P. Remes \& A. Eteläpelto (toim.) Muuttuva asiantuntijuus. Jyväskylän yliopisto. Koulutuksen tutkimuslaitos, 62-72.

ETELÄPELTO, A. (1998) The development of expertise in the information systems design. Jyväskylä Studies in Education, Psychology and Social Research 146. Jyväskylä: University of Jyväskylä.

ETELÄPELTO, A., \& LIGHT, P. (1999) Contextual knowledge in the development of design expertise. Teoksessa J. Bliss, P. Light, \& R. Säljö (Eds.) Learning Sites: Social and Technological Contexts for Learning. Oxford: Pergamon/Elsevier, 155-164.

ETELÄPELTO, A., \& TOURUNEN, E. (1999) Työelämälähtöinen projektiopiskelu tietojärjestelmän suunnittelijoiden asiantuntijuuden kehittämisessä. Teoksessa S. Honkimäki (toim.) Opetus, vuorovaikutus ja yliopisto. Jyväskylän yliopisto. Koulutuksen tutkimuslaitos, 73-99.

FOSTER, E., \& STEPHENSON, J. (1998) Work-based learning and universities in the U.K.: a review of current practice and trends. Higher Education Research \& Development 17 (2), 155-170.

GERBER, R. (1998) How do workers learn in their work? The Learning Organization 5 (4), 168-175.

GERBER, R., LANKSHEAR, C., LARSSON, S. \& SVENSSON, L. (1995) Self-directed learning in a work context. Education + Training 37 (8), 26-32.

HAGER, P. (1998). Understanding workplace learning: General perspectives. Teoksessa D. Boud (Ed.) Current issues and new agendas in workplace learning. Springfield (Va.): NCVER, 31-46.

HENRIKSSON, K. (1999) The collective dynamics of organisational learning. Lund Studies in Economics and Management 49. Lund University Press.

HUGHES, C. (1998) Practicum learning: perils of the authentic workplace. Higher Education Research \& Development 17 (2), 207-227.

JARVIS, P. (1992) Paradoxes of learning. San Francisco: Jossey-Bass.

JÄRVINEN, A., KOIVISTO, E. \& POIKELA, E. (2000) Oppiminen työssä ja työyhteisössä. Porvoo: WSOY.

KIVINEN, O. \& PELTOMÄKI, M. (1999) Apprenticeship training. Teoksessa O. Kivinen, H. Silvennoinen \& P. Puustelli (eds.) Work-based learning. Prospects and challenges. Helsinki: Ministry of Education, 97-118.

KIVINEN, O., \& SILVENNOINEN, H. (1999) Work and learning: challenges for the future. Teoksessa $\mathrm{O}$. Kivinen, H. Silvennoinen, \& P. Puustelli (Eds.), Work-based learning. Prospects and challenges. Helsinki: Ministry of Education, 163-179.

KOLB, D. A. (1984) Experiential learning. Experience as the source of learning and development. Englewood Cliffs, NJ: Prentice Hall.

KONTTINEN, E. (1997) Professionaalinen asiantuntijatyö ja sen haasteet myöhäismodernissa. Teoksessa J. Kirjonen, P. Remes \& A. Eteläpelto (toim.) Muuttuva asiantuntijuus. Jyväskylän yliopisto. Koulutuksen tutkimuslaitos, 48-61.

LASONEN, J. (1999) Enterprises as environments for workplace learning and training. Teoksessa J. Lasonen (Ed.), Workforce preparation in a global context. Jyväskylä: University of Jyväskylä. Institute for Educational Research, 199-216.

LAUNIS, K. \& ENGESTRÖM, Y. (1999) Asiantuntijuus muuttuvassa työtoiminnassa. Teoksessa A. Eteläpelto \& P. Tynjälä (toim.), Oppiminen ja asiantuntijuus. Juva: WSOY, 64-81.

LAVE, J. \& WENGER, E. (1991) Situated learning. Legitimate peripheral participation. Cambridge: Cambridge University Press.

LAVE, J. \& WENGER, E. (1999) Legitimate peripheral participation in communities of practice. Teoksessa R. McCormick \& C. Paechter (eds.) Learning \& knowledge. London: Paul Chapman Publishing in association with the Open University, 21-35

LEINHARDT, G., MCCARTHY YOUNG, K., \& MERRIMAN, J. (1995) Integrating professional knowledge: The theory of practice and the practice of theory. Learn-ing and Instruction 5, 401-408.

LYONS, J. (1999) Reflective education for professional practice: discovering knowledge from experience. Nurse Education Today 19, 29-34.

MEZIROW, J. et al. (1996) Uudistava oppiminen. Kriittinen reflektio aikuiskoulutuksessa (suom. Leevi Lehto). Helsingin yliopisto. Lahden koulutus- ja tutkimuskeskus.

MANDL, H. GRUBER, H. RENKL, A. (1996) Communities of practice toward expertise: Social foundation of university instruction. Teoksessa P.B. Baltes, U.M. Staudinger (eds.) Interactive minds. Lifespan perspectives on the social foundation of cognition. Cambridge University Press, 394-412

MARSICK, V.J. (1996) Toimintaoppiminen ja reflektio työpaikalla. Teoksessa J. Mezirow et al. (suom. Leevi Lehto). Helsinki: Helsingin yliopiston Lahden koulutus- ja tutkimuskeskus, 41-65.

MARSICK, V., J. , \& WATKINS, K. E. (1990) Informal and incidental learning in the workplace. London: Routledge.

MARTIN, E. (1998) Conceptions of workplace university education. Higher Education Research and Development 17 (2), 191-205.

MÄKINEN, J., OLKINUORA, E., \& TYNJÄLÄ, P. (1999). Growing demands of skills and knowledge: Learning and the acquisition of expertise in the information society. Analytic Teaching, 20 (1), 19-28.

NONAKA, I. (1994) A dynamic theory of organizational knowledge creation. Organization Science 5, 14-37.

ORR, J. E. (1996) Talking about Machines. An ethnography of a modern job. Ithaca, NY: IRL Press/ Cornell University Press. 
POIKELA, E. (1999) Kontekstuaalinen oppiminen. Acta Universitatis Tamperensis 675. Tampere: University of Tampere.

POIKELA, S. (1998) Ongelmaperustainen oppiminen. Uusi tapa oppia ja opettaa? Tampereen yliopiston opettajankoulutuslaitos. Ammattikasvatussarja 19

RANTALAIHO, K. (1994) Huomautuksia osaamisesta. Joensuun Yliopisto. Kasvatustieteen tiedekunnan selosteita 50.

REICH, R. B. (1991) The work of nations. New York: Vintage Books.

RESNICK, L. (1987) Learning in school and out. Educational Research 16 (9), 13-20.

ROGOFF, B. (1991) Social interaction as apprenticeship in thinking: guided participation in spatial planning. Teoksessa L. B. Resnick, J. M. Levine, \& S. D. Teasley (Eds.), Perspectives on socially shared cognition. Washington, DC: American Psychological Association, 349-363.

SANDBERG, J. (1994) Human competence at work. Göteborg: BAS.

SANDBERG, J. (2000) Understanding human competence at work: an interpretative approach. Academy of Management Journal 43 (1), 9-25.

SCHEIN, E. 1993. How can organizations learn faster? The challenge of entering the green room. Sloan Management Review 2 (34), 85-92.

SCHÖN, D.A. (1983) The Reflective Practitioner. London: Temple Smith.

SCHÖN, D. A. (1987) Educating the reflective practitioner. San Francisco: Jossey-Bass.

SENGE, P.M. (1990). The fifth discipline: the art and practice of the learning organization. New York: Doubleday Currency.

SEXTON, C.A. (1990) A comparative analysis of project method and learning project. International Journal of Lifelong Education 9, 81-98.

SFARD, A. (1998) On two metaphors for learning and dangers of choosing just one. Educational Researcher 27, 4-13.

STERN, D., RAHN, M., L, \& CHUNG, Y. (1998) Design of work-based learning for students in the United States. Youth \& Society 29 (4), 471-502.

TORRACO, R. J. (1999) Integrating learning with working: A reconception of the role of workplace learning. Human Recource Development Quarterly 10, 249-265.

TRACEY, B.J., KAVANAGH, M. J. \& TANNEBAUM, S. I. (1995) Applying trained skills on the job: The importance of the work environment. Journal of Applied Psychology 80 (2), 239-252.

TYNJÄLÄ, P. (1999) Towards expert knowledge? A comparison between a constructivist and a traditional learning environment in the university. International Journal of Educational Research 31 (5), 357-442.

TYNJÄLÄ, P., NUUTINEN, A., ETELÄPELTO, A., KIRJONEN, J., \& REMES, P. (1997) The Acquisition of professional expertise - A challenge for educational research. Scandinavian Journal of Educational Research 41, 475-494.

VALKEAVAARA, T. (1999) Ongelmien kauttako asiantuntijaksi? - Henkilöstönkehittäjien kokemuksia työnsä ongelmallisista tilanteista. Teoksessa A. Eteläpelto \& P. Tynjälä (toim.) Oppiminen ja asiantuntijuus. Juva: WSOY, 102-124

VIRKKUNEN, J. Engerström, Y., Helle, M., Pihlaja, J. \& Poikela, R. (1997) Muutoslaboratorio työn uudistamisen välineenä. Teoksessa P. Sallila \& J. Tuomisto (toim.) Työn muutos ja oppiminen. Helsinki: Kansanvalistusseura ja Aikuiskasvatuksen tutkimusseura, 77-103.

WENGER, E. 1998. Communities of Practice. Learning, meaning and identity. Cambridge University Press.

\section{Viitteet}

1 Tämä artikkeli liittyy Suomen Akatemian Tiedon tutkimusohjelman II-vaiheesta rahoitettavaan, professori Erkki Olkinuoran johtamaan hankkeeseen "Asiantuntijuus ja sen rakentaminen tietoyhteiskunnassa".

2 Emme toki väitä, että abstrakti ajattelu rajoittuiL si yksin symbolianalyyttisiin ammatteihin. Sitä toki tarvitaan kaikenlaisissa työtehtävissä, mutta symbolianalyytikoiden työssä siihen kytkeytyy intentionaalinen tiedon ja merkitysten käsittely, muovaaminen ja tuottaminen eli siis toiminta, joka paljolti muistuttaa koulutyötä.

Artikkeli saapui toimitukseen 15.6.2000. Toimituskunta teki julkaisupäätöksen kokouksessaan 23.10.2000. 